\title{
GAMBARAN PERSEPSI MAHASISWA KEPERAWATAN TENTANG KINERJA PRECEPTOR KLINIK
}

\author{
Rista Apriana (1), Sang Ayu Made Adyani (2) \\ Fakultas Ilmu Kesehatan UPN Veteran Jakarta 1,2 \\ Email: $\underline{\text { ristaapriana@upnvj.ac.id }}^{1}$; adyani.sangayu@upnvj.ac.id ${ }^{2}$
}

\begin{abstract}
ABSTRAK
Tujuan penelitian yang ingin dicapai pada penelitian ini adalah untuk mengetahui gambaran persepsi mahasiswa tentang kinerja preceptors pada proses bimbingan klinik di rumah sakit. Tujuan jangka panjang dalam penelitian ini adalah terwujudnya sistem pendidikan keperawatan yang berkualitas untuk menghasilkan lulusan keperawatan yang profesional dan memiliki daya saing baik nasional maupun internasional . Penelitian ini berjenis deskriptif. Preceptors disini adalah perawat yang berperan sebagai pembimbing dalam praktik klinik mahasiswa. Populasi dalam penelitian ini adalah mahasiswa keperawatan semester 5 yang telah melaksanakan praktek klinik. Jumlah sampel yang digunakan adalah 80 mahasiswa. Analisis univariat untuk menggambarkan persepsi mahasiswa tentang kinerja preceptors dalam pembimbingan praktik klinik di rumah sakit dalam bentuk tabel distribusi frekuensi. Hasil yang diperoleh adalah sebagian besar mahasiswa keperawatan mempersepsikan baik kinerja preceptor klinik yaitu sebesar 52,5\% dan sisanya 47,5 kurang baik.
\end{abstract}

Kata kunci: persepsi, kinerja, preceptor

\section{ABSTRACT}

The research objective is to find out the description of students' perceptions about the performance of preceptors in the clinical guidance process at the hospital. The long-term goal in this research is the realization of a quality nursing education system to produce nursing graduates who are professional and have national and international competitiveness. This research was descriptive study. Preceptors here were nurses who act as mentors in the practice of student. The population in this study was the 5th semester nursing students who have carried out clinical practiced. The number of samples used was 80 students. Univariate analysis was used to described student perceptions about the performance of preceptors in guiding clinical practice in hospitals in the form of frequency distribution tables. The results obtained were that most nursing students perceived good clinical preceptor performance that is $52.5 \%$ and the remaining 47.5 was perceived not good.

Keywords: perception, performance, preceptors

Alamat korespondensi: Fakultas Ilmu Kesehatan UPN Veteran Jakarta

Email: ristaapriana@upnvj.ac.id

\section{PENDAHULUAN}

Menurut Robbin (2008) persepsi merupakan proses di mana individu mengatur, menafsirkan dan memberi makna terhadap stimulus yang dilihat dan dengar oleh pancaindera. persepsi yang dihasilkan oleh individu dapat saja berbeda dengan objek yang sebenarnya, namun persepsi ini memegang peranan penting dalam pengambilan keputusan individu dalam berperilaku. Persepsi mahasiswa tentang kinerja preceptors dalam proses pembimbingan klinik (preceptorship) dirumah sakit sangat menentukan penilaian mahasiswa 
terhadap kualitas proses pembimbingan pratik klinik di rumah sakit. Rumah sakit merupakan wahana pembelajaran yang sangat efektif untuk mahasiswa keperawatan. Mahasiswa dapat secara langsung belajar dari kasus-kasus pasien yang dirawat sehingga mahasiswa mendapatkan pengalaman langsung untuk berinteraksi dengan pasien. Namun demikian mahasiwa praktik harus selalu didampingi dan difasilitasi oleh seorang preceptor. (Robbin, 2008)

Menurut Elley (2010) Program preceptorship dilakukan dengan tujuan membentuk peran dan tanggung jawab perawat yang professional dan berpengetahuan tinggi. Sehingga perawat mampu menunjukan kinerja yaitu perawatan yang aman, akuntabel, dapat dipercaya, mampu mengelola program perawatan pasien dan mampu berkomunikasi dengan baik. Preceptorship sangat membantu untuk meningkatkan kompetensi keterampilan perawat. Hasil penelitian yang dilakukan oleh Niela Sulung didapatkan hasil bahwa program perseptorship terbukti efektif untuk meningkatkan kompetensi perawat dan ketrampilan perawat. Perawat dituntut untuk memiliki berbagai ketrampilan yang memadai agar praktik pemberian asuhan keperawatan dilakukan sesuai dengan standar. (Elley, 2010)

Perawat profesional tidak lahir dengan instan melainkan melalui proses pendidikan keperawatan yang komprehensif. Mahasiswa keperawatan merupakan calon perawat profesional yang dituntut untuk memiliki kompetensi dalam memberikan pelayanan kepada pasien nantinya. Proses belajar keperawatan dicapai dengan berbagai metode pembelajaran salah satunya adalah Pembelajaran klinik. Pembelajaran klinik (preceptorship) sangat berkontribusi dalam meningkatkan kemampuan kognitif, psikomor dan afektif mahasiswa.

Kualitas pembimbingan klinik memegang peranan yang sangat penting untuk menciptakan sistem pendidikan keperawatan yang berkualitas. Keberhasilan pembimbingan klinik ditentukan oleh kualitas seorang preceptor. Preceptor memiliki peran penting antara lain membantu proses transisi mahasiswa dari pembelajaran ke praktisioner sekaligus mengurangi dampak "syok realita" dan memfasilitasi mahasiswa keperawatan untuk beradaptasi terhadap lingkungan barunya. Preceptor juga berperan dalam memberikan pandangan dan harapan preceptee akan memiliki kemampuan yang sama dengan preceptor-nya. Preceptor yang menjalankan peran dan kinerjanya dengan baik akan berdampak positif terhadap kemampuan dan kepercayaan diri mahasiswa. ( Dermawan, 2012).

Kinerja didefinisikan sebagai prestasi kerja terhadap tugas dan tanggungjawab yang diberikan kepada individu (Gibson, 2012). Tanggung jawab seorang preceptor antara lain: 1. Mencari tahu tentang kebutuhan perseptee dalam bimbingan, 2. Membantu Perseptee menentukan tujuan bimbingan yang ingin dicapai, 3. Menanyakan kepada perseptee tentang tugas yang dibebankan, 4. Memperkenalkan tentang sikap perseptor dan kesempatan bimbingan. 5. Menjajaki psikologis perseptee tentang kesiapan bimbingan dan Memberi dukungan perseptee untuk self - assessment. Kinerja yang baik dari preceptor sangat berdampak pada efektifitas proses pembimbingan klinik (Dermawan, 2012)

Hasil penelitian yang dilakukan oleh Maria Yunita I tentang pengalaman dukungan preceptor pada perawat baru di dapatkan hasil masih adanya preceptor yang merasa tidak menjalankan tanggung jawabnya dikarenakan kesibukan perawat karena selain bertugas sebagai preceptor, perawat tersebut juga bertanggung jawab terhadap perawatan pasien sehingga ini menjadi salah satu kendala dalam pelaksanaan program pembimbingan klinik. Namun pelaksanan program preceptorship ini sangat penting karena efektif untuk mengurangi turn-over perawat baru, mengurangi biaya akibat turn-over perawat, meningkatkan kualitas pelayanan keperawatan serta meningkatkan kualitas pengembagan profesionalisme perawat. (Tso-Ying Lee, 2009) 
Terkait dengan latar belakang dan identifikasi masalah yang peneliti kemukakan, maka perumusan masalah yang akan di teliti adalah: bagaimana gambaran persepsi mahasiswa tentang kinerja preceptor dalam pembimbingan praktik klinik di rumah sakit?

Tujuan penelitian yang ingin dicapai pada penelitian ini adalah untuk mengetahui gambaran persepsi mahasiswa tentang kinerja preceptor dalam proses pembimbingan klinik mahasiswa di rumah sakit.

\section{METODE PENELITIAN}

Jenis penelitian ini adalah deskriptif non eksperimental yaitu jenis penelitian yang hanya menggambarka yang ada dilapangan tanpa melakukan intervensi apapun kepada subjek penelitian. Populasi yang menjadi responden dalam penelitian ini adalah mahasiswa S1 Keperawatan sebesar 438 mahasiswa.. Tekhnik pengambilan sampel menggunakan purposive sampling dengan kriteria inklusi meliputi: Mahasiswa S1 Ilmu Keperawatan Semester 5 Telah selesai mengikuti praktik klinik keperawatan dan Bersedia menjadi responden penelitian sedangkan kriteria Kriteria eksklusinya antara lain: Mahasiswa yang ijin atau tidak hadir pada saat dilakukan pengambilan data Mengundurkan diri menjadi responden dalam penelitian. Jumlah sampel dalam penelitian ini adalah 80 mahasiswa. Penelitian ini dilakukan pada bulan Agustus 2019.

Alat ukur yang digunakan untuk mengukur persepsi mahasiswa tentang kinerja preceptors adalah menggunakan kuisioner yang dikembangkan sendiri oleh peneliti yang telah dilakukan uji validitas dan reliabilitas terlebih dahulu pada mahasiswa D3 keperawatan tingkat 2 yang telah melaksanakan praktik klinik sebanyak 30 mahasiswa. Uji validitas dilakukan menggunakan uji pearson product moment sedangkan uji reliabilitas dilakukan menggunakan uji alpha-cronbach. Uji validitas telah dilakukan pada bulan Agustus 2019 pada mahasiswa Prodi D3 Keperawatan tingkat 2 yang berjumlah 30 mahasiswa didapatkan hasil seluruh item pertanyaan dinyatakan valid dengan rentang nilai $\mathrm{r}$ total terendah adalah 0,632 dan tertinggi 0,917 dan dinyatakan reliabel dengan nilai alphacronbach sebesar sebesar 0,768 yang berarti kuisioner dinyatakan reliabel karena nilai alpha cronbach > dari 0,6.

Analisis univariat dilakukan untuk mengetahui gambaran persepsi mahasiswa tentang kinerja preceptors dalam pembimbingan praktik klinik di rumah sakit dalam bentuk tabel distribusi frekuensi dengan kategori persepsi baik jika skor $\geq$ mean dan persepsi kurang baik skor < mean.

\section{HASIL DAN PEMBAHASAN}

Penelitian ini di lakukan di di lingkungan fakultas Ilmu Kesehatan UPN Veteran Jakarta yang berlokasi di Limo Depok Jawa Barat. Responden dalam penelitian ini mahasiwa semester 5 program Studi S1 Ilmu Keperawatan yang telah menjalani praktik klinik dirumah sakit dan sudah mendapatkan bimbingan praktik dari preceptor klinik di rumah sakit. Jumlah responden dalam panelitian ini adalah 80 mahasiswa yang telah memenuhi kriteria sebagai responden.

Tabel 1. Gambaran Persepsi Mahasiswa Tentang Kinerja Preceptor September 2019, $n=80$

\begin{tabular}{ccccc}
\hline Min-Max & Mean & Median & Modus & S.D \\
\hline $40-100$ & 74,7 & 76,5 & 81 & 14,6 \\
\hline
\end{tabular}


Hasil analisis tersebut menunjukkan bahwa presepsi nilai tertinggi mahasiswa sebesar 100, Nilai tersebut merupakan skor tertinggi maksimum dalam pengisian kuisioner, hal tersebut menunjukkan bahwa terdapat preceptor yang memiliki kinerja sangat baik dalam membimbing mahasiswa. Preceptor telah melaksanakan tahap-tahap proses presetorship dengan sangat baik yang meliputi tahap orientasi, pelaksanaan dan evaluasi. Preceptor yang baik dipersepsikan oleh perawat baru menurut penelitian yang dilakukan oleh Genevieve J.H. Quek dkk, 2019 antara lain : yang pertama peran preceptor dalam sosilaisasi, peran ini bertujuan untuk menjalin hubungan yang baik antara preceptor-preceptee. Sebelum proses bimbingan klinik terlaksana maka preseptor harus memastikan bahwa mahasiwa merasa nyaman, tidak takut tidak cemas dalam proses bimbingan tersebut sehingga kesabaran untuk menjelaskan, keramahan sikap perlu dimiliki oleh seorang preseptor, peran ini juga menekankan pada preseptor untuk mneunjukkan sikap bersemangat, menghargai rasa ingin tahu mahasiswa dan selalu terbuka untuk mengadakan diskusi dengan mahasiswa keperawatan. Peran yang kedua adalah peran memandirikan mahasiswa keperawatan untuk secara bertahap dapat memberikan asuhan keperawatan kepada pasien mulai dari tindakan yang paling sederhana sampai dengan tindakan yang sulit secara mandiri.

Peran yang ketiga adalah peran komunikasi dan penggunaan teknologi. Peran ini memungkinkan perceptee dapat menghubungi perceptornya melalui pesan elektronik, media sosial ketika ada yang akan perlu ditanyakan sementara mereka sedang tidak dalam satu shift. Peran yang terakhir adalah peran pelibatan manajer keperawatan dalam proses preceptorship. Keempat peran tersebut perlu dimiliki oleh seorang preceptor klinik supaya proses belajar mengajar dalam wahana pembelajaran dapat berjalan dengan efektif.

Skor terendah dari persepsi mahasiswa tentang kinerja preceptor adalah 40, nilai ini menunjukkan masih ada preceptor yang belum menjalan perannya dengan baik sebagai pembimbing klinik. Nilai rata-rata persepsi mahasiwa tentang kinerja preceptor adalah 74,7 dan nilai tengahnya adalah 76,5 dengan nilai yang sering muncul adalah 81 dan standar deviasi sebesar 14,6 .

Tabel 2. Hasil Uji Normalitas

\begin{tabular}{cc}
\hline nilai Z & P-value \\
\hline 0,911 & 0,378 \\
\hline
\end{tabular}

Dari hasil uji normalitas didapatkan hasil p-value sebesar 0,378 maka distribusi normal karena $\mathrm{p}$-value $>0,05$. Hasil tersebut untuk menentukan nilai tengah yang akan digunakan dalam menentukan kategori persepsi baik dan kurang baik menggunakan nilai mean (rata-rata).

Tabel 3. Gambaran distribusi frekuensi Persepsi Mahasiswa Tentang Kinerja Preceptor September 2019, $n=80$

\begin{tabular}{ccc}
\hline persepsi & Jumlah (n) & Persentase (\%) \\
\hline baik & 42 & 52,5 \\
kurang & 38 & 47,5 \\
\hline total & $\mathbf{8 0}$ & $\mathbf{1 0 0}$ \\
\hline
\end{tabular}

Dari tabel hasil tersebut dapat diperoleh bahwa sebagian besar mahasiswa memiliki persepsi yang baik tentang kinerja preceptor klinik di rumah sakit yaitu sebesar $52,5 \%$. hal tersebut sejalan dengan penelitian yang dilakukan oleh Eira Kristiina Hyrkas dkk, 
2014 menunjukkan sebagian besar tingkat kepuasan perceptor dan perceptee adalah tinggi yaitu sebesar 98,7\% dan 97,3\%. Hal tersebut menunjukkan bahwa perceptor telah melaksankan perannya dengan baik. Mereka sangat berkomitmen dalam melalukan bimbingan klinik kepada mahasiswa karena mereka menganggap bahwa dengan membimbing mahasiswa ada banyak manfaat yang dapat diperoleh antara lain meningkatkan kemampuan dalam mengajar, mempunyai kesempatan untuk bertemu dan membimbing mahasiswa dan perawat baru, berbagi ilmu pengetahuan dan sekaligus meningkatkan ilmu pengetahuan, serta yang paling penting adalah untuk meningkatkan kepuasan kerja.

Terdapat jumlah yang cukup besar juga mahasiswa yang memiliki persepsi kurang baik tentang kinerja preceptor klinik yaitu sebesar 47,5\%. Kurang efektifnya kinerja perceptor klinik dapat dipengaruhi beberapa hal antara lain: kurangnya komitmen untuk melakukan pembimbingan klinik yang disebabkan oleh persepsi tentang kurangnya manfaat, penghargaan dan dukungan dalam melakukan pembimbingan klinik. (Eira Kristiina Hyrkas dkk, 2014)

Tabel 4. Gambaran Kuisioner

\begin{tabular}{lcccc}
\hline \multicolumn{1}{c}{ item pertanyaan } & min-max & mean & s.d & total \\
\hline \multicolumn{1}{c}{ ORIENTASI } & & & & \\
mencari tahu kebutuhan belajar & $1-5$ & 3,43 & .952 & 274 \\
membantu menetukan tujuan & $1-5$ & 3.71 & .996 & 297 \\
menanyakan tentang target & $1-5$ & 3.89 & .900 & 311 \\
menawarkan kesempatan bimbingan & $2-5$ & 3.75 & .879 & 300 \\
menggali kesiapan psikologis & $1-5$ & 3.29 & .983 & 263 \\
memberikan dukungan & $1-5$ & 3.64 & 1.009 & 291 \\
PELAKSANAAN & & & & \\
mendukung perceptee untuk mengetahui & $1-5$ & 3.26 & 1.064 & 261 \\
kelemahan dan kelebihan diri sendiri & $1-5$ & 3.52 & .941 & 282 \\
menanyakan dan mengklarifikasi ide-ide & $2-5$ & 3.84 & .920 & 307 \\
memberikan saran perbaikan & $1-5$ & 3.60 & .963 & 288 \\
membuat catatan terkait point penting & $1-5$ & 3.83 & .897 & 306 \\
mengevalusi kembali kemampuan & $1-5$ & 3.86 & .924 & 309 \\
memberikan motivasi untuk selalu percaya diri & $1-5$ & 3.88 & .905 & 310 \\
menjadi role-model & $1-5$ & 3.88 & .933 & 310 \\
bersikap ramah (friendly) & $1-5$ & 3.71 & 1.009 & 297 \\
menumbuhkan rasa nyaman & $1-5$ & 4.00 & .968 & 320 \\
memberikan pendampingan pada saat & & 3.86 & .853 & 309 \\
mellakukan tindakan & $2-5$ & & & \\
menggunakan cara yang tepat dalam menegur & & 3.80 & .833 & 304 \\
EVALUASI & $2-5$ & 3.61 & .864 & 289 \\
menilai kemajuan yang dicapai & $2-5$ & 3.91 & .860 & 313 \\
membuat rencana tindak lanjut & $2-5$ & & & \\
memberikan motivasi untuk selalu & & & & \\
meningkatkan kemampuan diri & & & & \\
\hline
\end{tabular}

Dari hasil analisis kuisioner dapat dilihat bahwa skor tertinggi kinerja perceptor klinik adalah pada tahap evaluasi yaitu memberikan motivasi untuk selalu meningkatkan kemampuan diri yaitu total skor sebesar 313 dan nilai rata-rata 3,91. Hal tersebut menunjukkan bahwa peran tersebut telah dilaksankan paling baik oleh perceptor klinik. 
Kemampuan memotivasi peserta didik ini memberikan dampak sangat baik dalam proses pembinbingan klinik supaya selalu berusaha meningkatkan kemmapuan diri.

Hasil analisis kuisioner diatas juga sebaliknya menunjukkan bahwa skor terendah dari tahap kinerja perceptor ditunjukkan pada tahap kinerja pelaksanaan dalam mendukung perceptee untuk mengetahui kelemahan dan kelebihan diri sendiri yaitu sebesar 316 dengan nilai rata-rata 3,26. dukungan yang kurang ini besar kaitannya dengan kurangnya komitmen perceptor dalam melakukan proses bimbingan klinik.

\section{KESIMPULAN}

Hasil yang diperoleh adalah sebagian besar mahasiswa keperawatan mempersepsikan baik kinerja preceptor klinik yaitu sebesar 52,5\% dan sisanya 47,5 mempersepsikan kurang baik.

\section{SARAN}

Rekomendasi yang dapat diberikan untuk perceptor adalah untuk meningkatkan kinerjanya dalam membimbing mahasiswa wahana praktik dengan cara untuk menanamkan komitmen yang tinggi untuk senantiasa membimbing mahasiswa penuh dengan bersemangat, tanggung jawab demi terwujudya suasana belajar yang kondusif sehingga proses belajar mengajar dapat berjalan efektif. Bagi manajemen rumah sakit agar dapat menyusun program preceptorship yang bekerja sama dengan institusi pendidikan dalam bentuk pelatihan-pelatihan, training, coaching untuk meningkatkan kemampuan perceptor serta memberikan reward dan penghargaan baik dalam bentuk finansial maupun non finansial bagi perceptor klinik.

\section{DAFTAR PUSTAKA}

Dermawan, D. 2012. Preceptship dan mentorship dalam keperawatan. media publikasi Profesi. Vol.8

Eira Kristiina Hyrkas1, Deborah Ann Linscott1, James P. Rhudy, Jr. 2014. Evaluating preceptors' and preceptees' satisfaction concerning preceptorship and the preceptor-preceptee relationship. Journal of Nursing Education and Practice, Vol. 4, No. 4, ISSN 19120 254040 E-ISSN 1925-4059.

Eley, S.M. 2010.The Power of preceptorship.http://www.rnjournal.com/journal of nursing/the power of preceptorship 2.htm.

Gibson JL, John MI, James HDJ. 2012. Organizations. NewYork: McGraw-Hill.

Genevieve J.H. Quek, Grace H.L. Ho, Norasyikin B. Hassan, Sarah E.H. Quek, Shefaly Shorey. 2019. Perceptions of preceptorship among newly graduated nurses and preceptors: A descriptive qualitative study, Nurse Education in Practice,Volume 37, Pages 62-67, ISSN 1471-5953, https://doi.org/10.1016/j.nepr.2019.05.001.

Janice Ampil Miller, Ed.D. 2013. The Lived Experiences Of Nurses Transitioning To A Preceptor Role. Department of Counseling, Adult and Higher Education. Northern Illinois University. Gene Roth and Larinda Dixon, Co-Directors

Lee, Tso-Ying, Tzeng, Wen-Chii, Lin, Chia-Huei, Yeh, Mei-Ling. 2009. Effects of a preceptorship programme on turnover rate, cost, qualiy and professional development. Journal of Clinical Nursing vol. 18 Pages 1217-1225 https://doi.org/10.1111/j.1365-2702.2008.02662.x.

Maria Yunita, Indriani dkk. Pengalaman dukungan preceptor pada perawat baru selama proses magang di rumah sakit santo borromeus Bandung. Tesis. http://www.ejournal. stikesborromeus.ac.id

Stephen P. Robbin, Timothy A. Judge. 2008. Perilaku Organisasi, organizational behavior, ed 12th. Jakarta : Salemba Empat 